\title{
Light and electron microscopy study of capillaries in normal and inflammatory human synovial membrane
}

\author{
ANTOINE DRYLL, JULietTE LANSAMAN, PAUle CAZALis, ANDRÉ P. \\ PELTIER, AND STANISLAS DE SEZE
}

From the Laboratoire de Microscopie Électronique, Clinique Rhumatologique, Hôpital Lariboisière, Paris, France

SUMMARY Synovium aspirated from the knee joint by trochar was studied by light and electron microscopy in 40 cases of inflammatory arthritis and in 10 controls. The morphology of synovial capillaries, extravascular plasma diffusion, interendothelial vascular gaps, extracapillary blood cell migration, vascular congestion, endothelial hyperplasia, and obliteration of the capillary lumen by endothelial cells were compared in normal and inflammatory synovia. Inflammatory synovitis was? characterised by the number and diversity of blood cells migrating through the interendothelial $\vec{\circ}$ pathway out of the capillary lumen. Polymorphonuclear leucocytes were the blood cells most often seen at interendothelial junctions. No other capillary changes that might be related to synovial inflammation were found.

Despite their important role in inflammatory processes the capillaries of human synovial membrane have so far received little attention. In a light microscopy study of rheumatoid synovitis Kulka (1966) described a segmental angiopathy affecting the venules and capillaries. In vital microscopy of rheumatoid synovial membrane Brånemark et al. (1963) found a venular dilatation with arteriolovenular shunts. In an electron microscopy study of rheumatoid synovitis Bierther and Wegner (1971) found a progressive transformation of endothelial cells to fibroblasts. On the other hand, Brånemark et al. (1969) did not find ultrastructural alterations of the capillaries in rheumatoid synovial membrane.

In our present study we therefore aimed to define by light and electron microscopy what changes in synovial capillaries might be caused by inflammation.

\section{Material and methods}

A trochar synovial biopsy of the knee was performed in 50 patients, 40 of whom had inflammatory arthritis and 10 (who were used as controls) had mechanical disorders of the knee. The $\mathbf{4 0}$ cases of arthritis included 24 of rheumatoid arthritis according to the criteria of the American Rheumatism

Received for publication 25 October 1976
Association (Ropes et al., 1958)-12 cases being classical and 12 being definite rheumatoid arthritis13 cases of monoarthritis without rheumatoid factor을 and with a clinical course of at least 3 months; and one case each of gout, systemic lupus erythematosus, and filarial arthritis.

Histopathological examination of the synoviaio membrane by light microscopy in the $\mathbf{4 0}$ cases of inflammatory arthritis showed three types of inflam mation (Table): (1) rheumatoid type with at leasê three of the characteristics of rheumatoid synovitis according to the ARA criteria (Ropes et al., 1958) ? (2) subacute type characterised by moderate villous hypertrophy, proliferation of cells in the margina? layer without palisading, and moderate diffuse celN infiltration particularly with lymphocytes; and (3)

Table Histopathological type of inflammatory synovitis according to clinical diagnosis

\begin{tabular}{|c|c|c|c|}
\hline \multirow[t]{2}{*}{ Clinical diagnosis } & \multicolumn{3}{|c|}{ Histopathological type } \\
\hline & $\begin{array}{l}\text { Rheuma- } \\
\text { toid }\end{array}$ & Subacute & Sclerous \\
\hline $\begin{array}{l}\text { Classic rheumatoid arthritis* } \\
\text { Definite rheumatoid arthritis* } \\
\text { Monoarthritis of knee } \\
\text { Miscellaneous }\end{array}$ & $\begin{array}{l}6 \\
6 \\
5 \\
2\end{array}$ & $\begin{array}{l}5 \\
5 \\
5 \\
1\end{array}$ & $\begin{array}{l}1 \\
1 \\
3 \\
-\end{array}$ \\
\hline
\end{tabular}


sclerous type characterised by discrete or no villous hypertrophy, marginal layer reduced to one or two layers of cells, discrete diffuse cell infiltration of monohistiocytic type, and striking development of collagen fibres in the deep layer.

The histological appearance of the synovial membrane was normal in the 10 cases of mechanical disorder of the knee used as controls.

Biopsy specimens sliced into fragments of $1 \mathrm{~mm}^{2}$ were immediately fixed in a $2.5 \%$ glutaraldehyde solution in $0.1 \mathrm{M}$ phosphate buffer $\mathrm{pH} 7.3$ at $4^{\circ} \mathrm{C}$ for two hours. The fragments were rinsed for one night, in $0.1 \mathrm{M}$ phosphate buffer $\mathrm{pH} 7.3$ at $4^{\circ} \mathrm{C}$. After postfixation in a $2 \%$ osmium tetroxide solution in phosphate buffer for one hour the fragments were dehydrated in ethanol and embedded in a mixture of Epon and Araldite. Sections $1 \mu \mathrm{m}$ thick were stained with toluidine blue and examined with the light microscope. Ultrathin sections were cut with an ultramicrotome (Reichert OmU 2), stained with a $5 \%$ aqueous uranyl solution, and then with lead citrate. The sections were examined with a Philips EM 300 electron microscope at $40 \mathrm{kV}$. A minimum of six blocks containing capillary-rich areas were examined for each of the 50 biopsies. In all, we examined 7500 capillaries with a minimum of 100 , a maximum of 300 , and an average of 150 for each biopsy.

\section{Resuits}

\section{LIGHT MICROSCOPY}

In light microscopy attention was paid to capillary congestion, endothelial hyperplasia, and obliteration of the capillary lumen by endothelial cells. The incidence of capillary congestion was identical in proportion in inflammatory synovitis $(21 / 40)$ and in controls (5/10). Endothelial hyperplasia was estimated by the count of endothelial nuclei in synovial capillaries. The mean number of endothelial nuclei per capillary was similar in controls $(2 \cdot 1)$ in rheumatoid arthritis (2), and in other inflammatory synovitis $(1 \cdot 8)$. The incidence of obliteration of the capillary lumen by endothelial cells was proportionately similar in inflammatory synovitis (34/40 with an average of 2.5 obliterations for 100 capillaries) and in controls (7/10 with an average of $2 \cdot 3$ obliterations for 100 capillaries).

\section{ELECTRON MICROSCOPY}

Morphology of synovial capillaries In both the inflammatory synovitis and control cases the following types of capillaries, according to Simon's (1965) classification, were found with identical frequency: (1) Continuous capillaries with flat (Fig. 1) or high (Fig. 2) endothelium. Neither in inflammatory

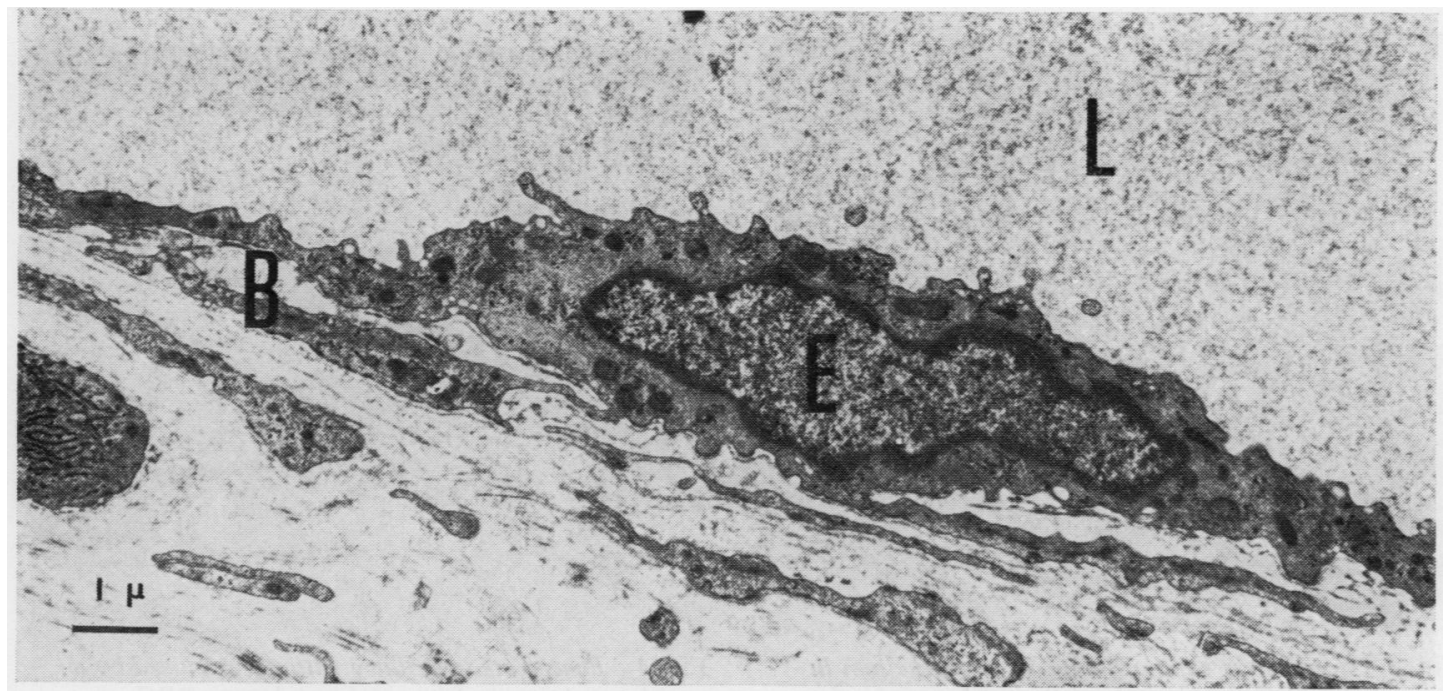

Fig. 1 Continuous capillary with flat endothelium in normal synovial membrane. $L=$ lumen, $E=$ endothelial cell, $B=$ basement membrane. Original magnification $\times 3300$ 


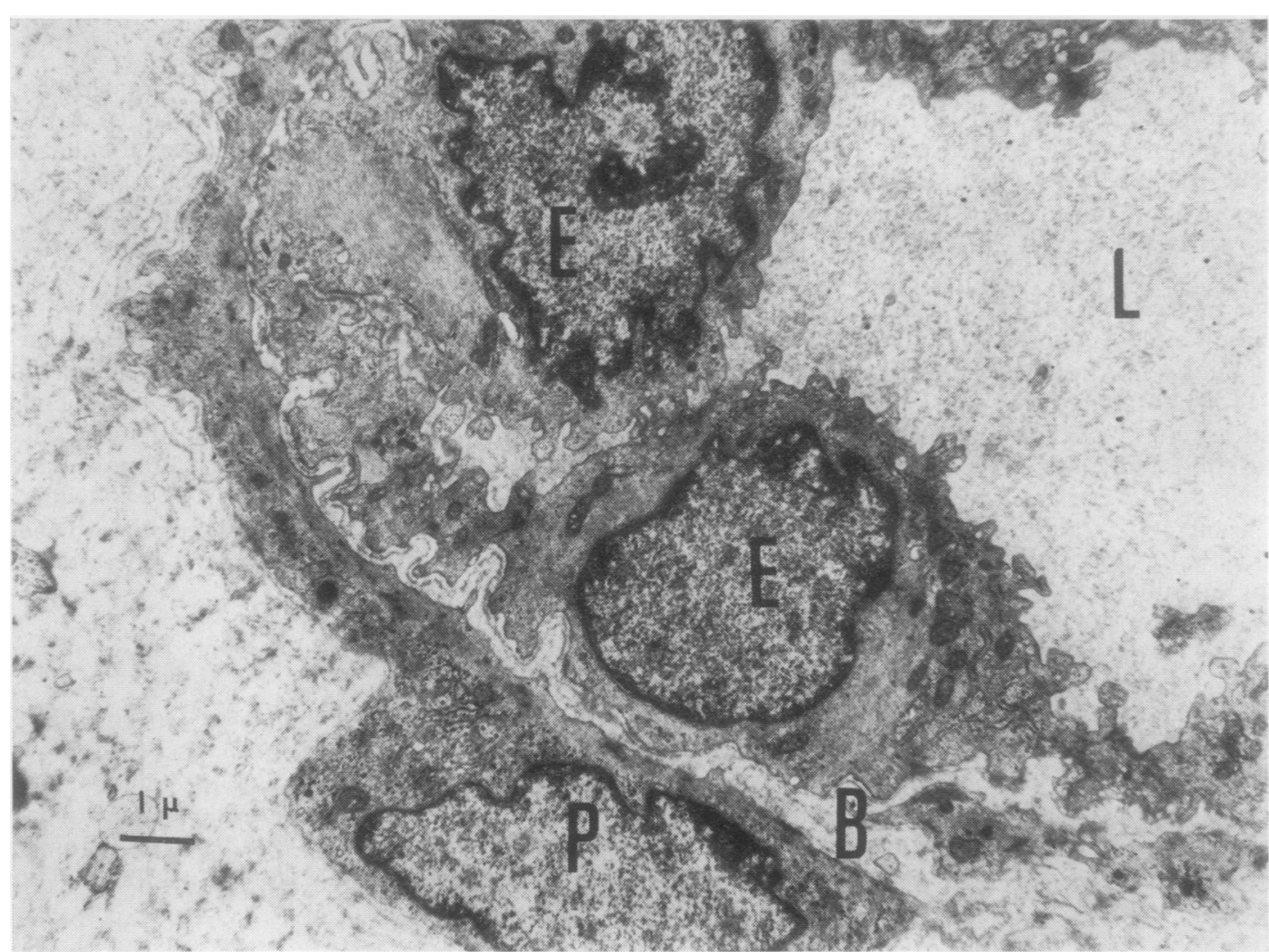

Fig. 2 Continuous capillary with high endothelium in rheumatoid synovitis. Cytoplasmic organelles and microfibrils and pinocytotic vesicles have the same appearance as in flat endothelium. $L=$ lumen, $E=$ endothelial cell, $B=$ basement membrane, $P=$ pericyte. Original magnification $\times 3300$

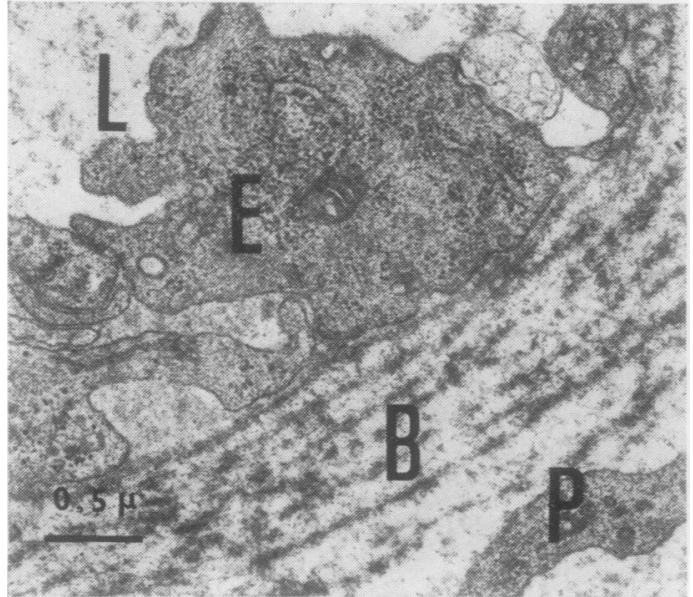

Fig. 3 Continuous capillary with flat endothelium in normal synovial membrane, multilayered pattern of basement membrane. $L=$ lumen, $E=$ endothelial cell, $B=$ basement membrane, $P=$ pericyte. Original magnification $\times 10000$

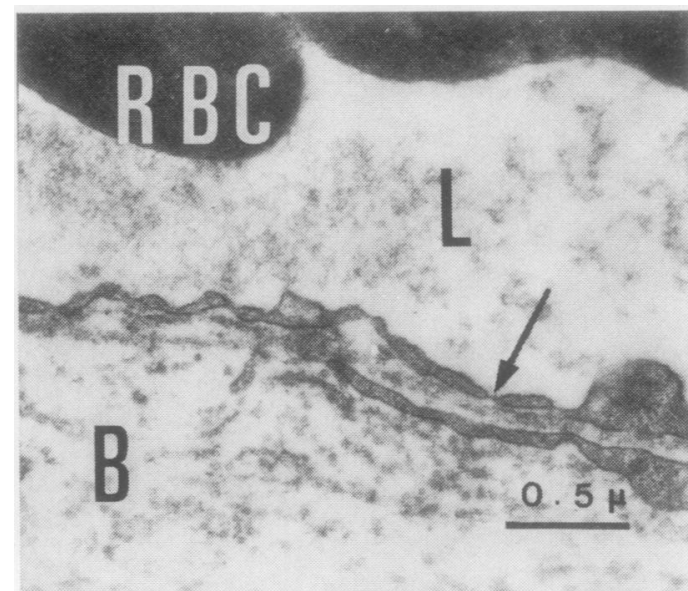

Fig. 4 Fenestrated capillary with pores closed by a membrane in normal synovial membrane. $R B C=$ red blood cell, $L=$ lumen, $B=$ basement membrane, arrow $=$ pore closed by a membrane. Original magnification $\times 10000$ 
synovitis nor in controls did high endothelia appear to have greater cell activity than flat endotheliaindeed, cytoplasmic organelles and microfibrils and pinocytotic vesicles had a similar appearance in both. In these continuous capillaries the basement membrane sometimes showed a multilayered pattern (Fig. 3), which was found as often in inflammatory synovitis as in controls. (2) Fenestrated capillaries of various types-capillaries with pores closed by a membrane (Fig. 4), capillaries with pores without membrane (Fig. 5), and transitional forms between continuous and fenestrated capillaries. All types were seen equally often in inflammatory synovitis and in controls.

Extravascular plasma diffusion, interendothelial gaps A pattern suggesting a plasma impregnation of basement membrane was seen in all types of synovial capillaries (Fig. 6). In some capillaries with continuous endothelium plasma appeared to penetrate into the basement membrane through large interendothelial gaps (Fig. 7). Extravascular plasma diffusion and interendothelial gaps were seen with an identical frequency in all 50 biopsies.

Extracapillary blood cell migration In the controls extracapillary blood cell migration was rare and was restricted to red blood cells. In inflammatory synovitis extracapillary blood cell migration was much more frequent, mostly of polymorphonuclear leucocytes and only occasionally of red blood cells, platelets, lymphocytes, and blast cells. All these

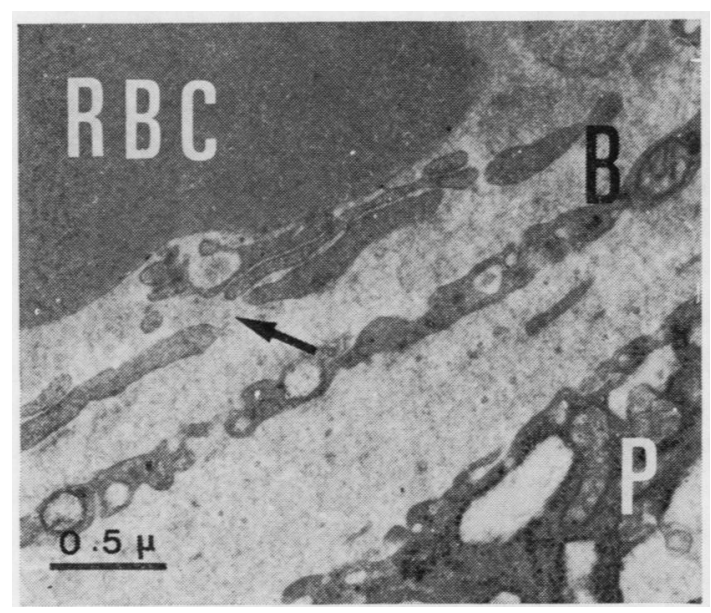

Fig. 5 Fenestrated capillary with pores without membrane in normal synovial membrane. $R B C=$ red blood cell, $B=$ basement membrane, $P=$ pericyte, arrow = pore without membrane. Original magnification $\times 10000$ blood cells migrate out of the capillary lumen following an interendothelial pathway (Fig. 8).

Vascular congestion and obliteration of capillary lumen by endothelial cells No ultrastructural change in the capillary wall was seen when the capillary lumen was obstructed by packed red blood cells. In cellular obliteration of the capillary lumen the endothelial cells appeared to coalesce by a junction of their intraluminal plasmatic membrane. Important ultrastructural changes in the endothelial cells were often seen in both inflammatory synovitis and controls, with expansion (Fig. 9) or retraction (Fig. 10) of the cytoplasma.

\section{Discussion}

\section{LIGHT MICROSCOPY}

In his extensive study of vascular derangement in rheumatoid arthritis Kulka (1966) stated that endothelial hypertrophy and hyperplasia with varying degrees of encroachment on the vascular lumen were typical of the proliferative lesions as exemplified by the synovitis. In a semiquantitative approach to these capillary modifications no characteristic changes related to synovial inflammation were found in our light microscopy study.

\section{ELECTRON MICROSCOPY}

Morphology of synovial capillaries The repartition of the different types of capillaries (continuous, fenestrated) was identical in all 50 biopsies. Thus in

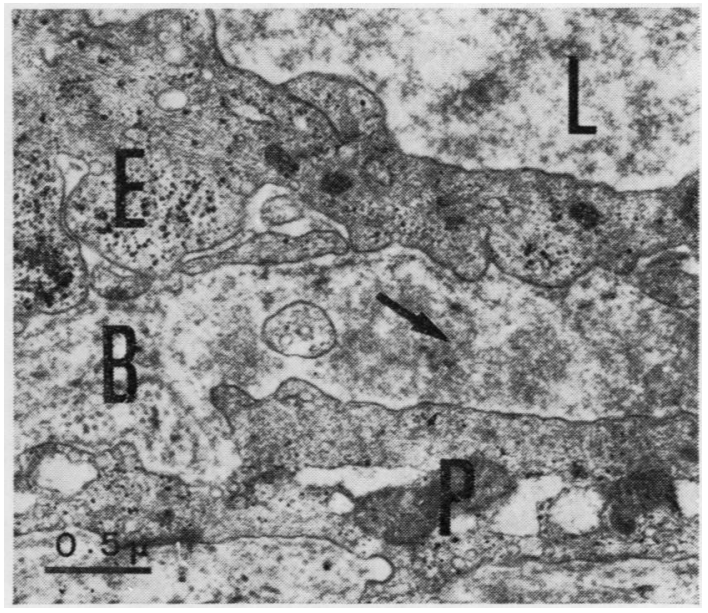

Fig. 6 Continuous capillary with flat endothelium in normal synovial membrane, pattern suggesting plasma impregnation of basement membrane (arrow). $L=$ lumen, $E=$ endothelial cell, $B=$ basement membrane, $P=$ pericyte. Original magnification $\times 10000$ 


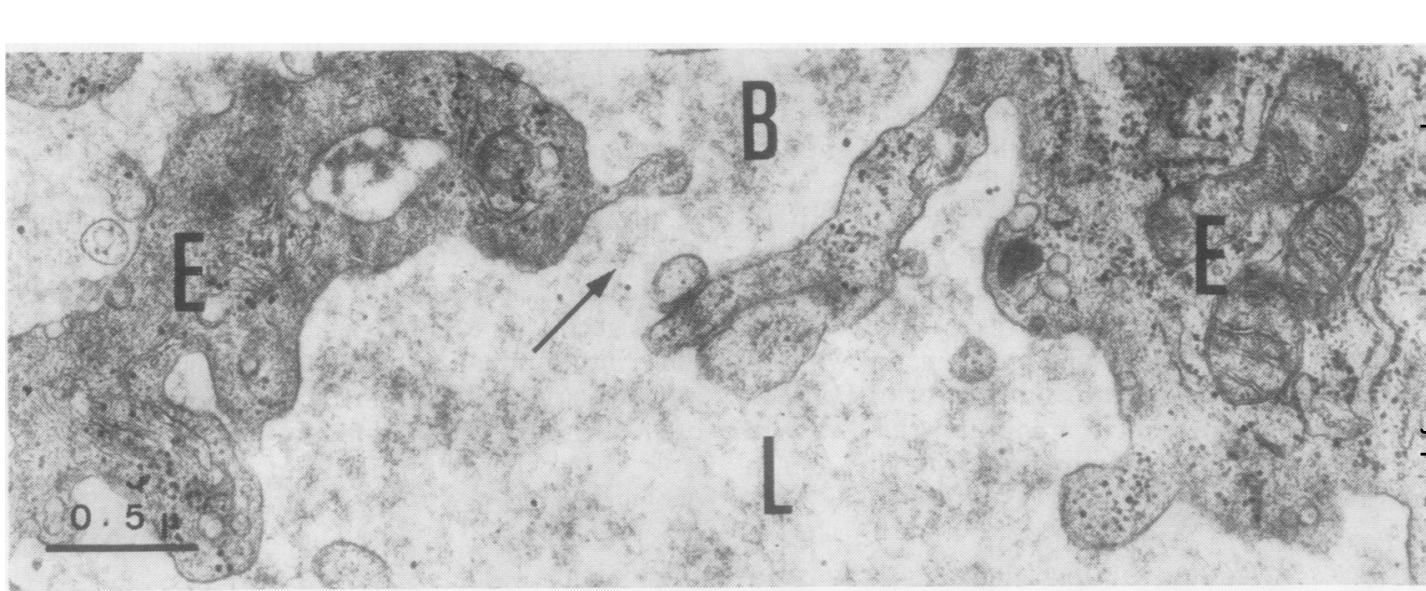

Fig. 7 Continuous capillary with flat endothelium in normal synovial membrane, interendothelial gap (arrow). $L=$ lumen, $E=$ endothelial cell, $B=$ basement membrane. Original magnification $\times 10000$

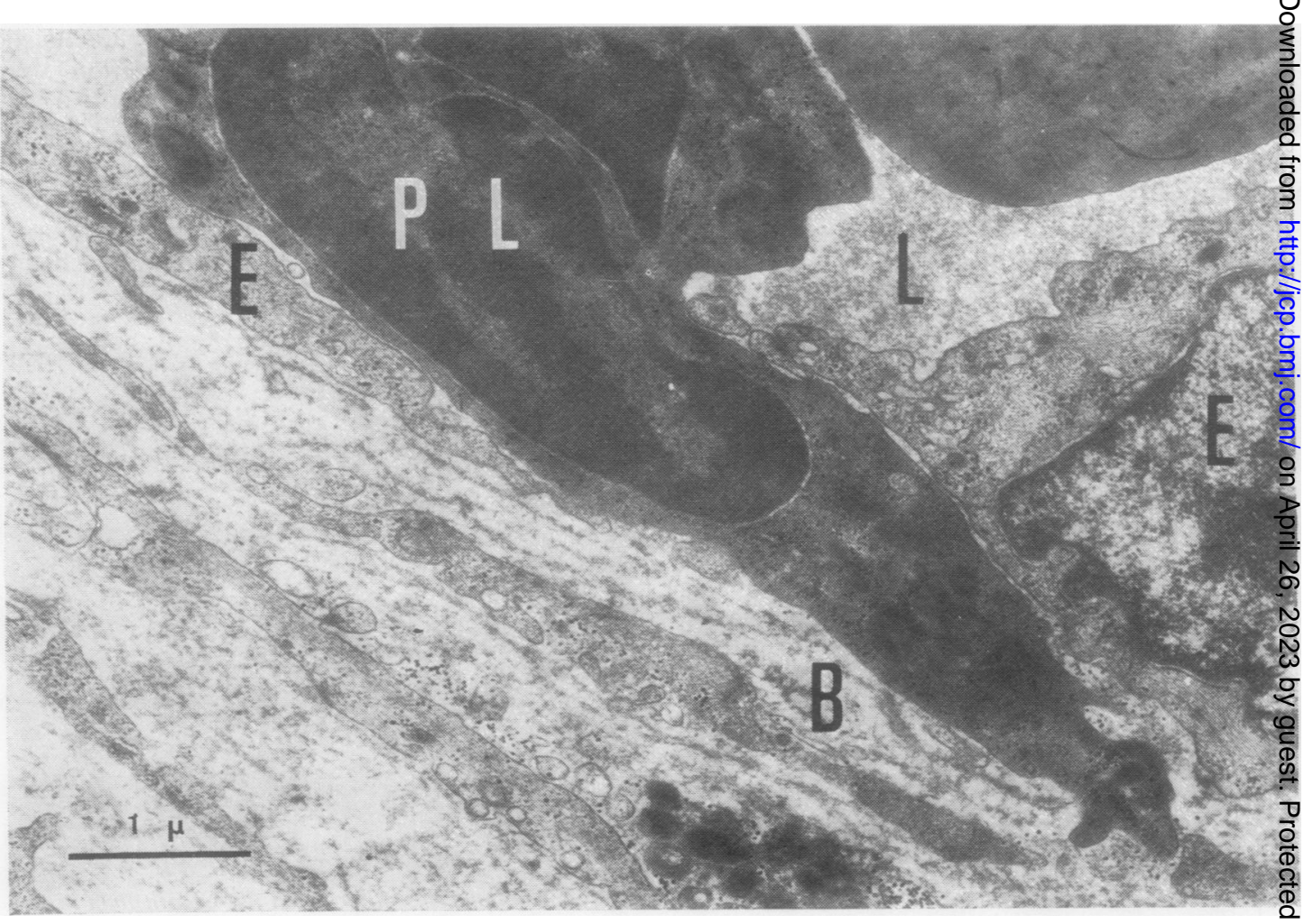

Fig. 8 Extracapillary polymorphonuclear leucocyte migration through interendothelial pathway in rheumatoid synovitis. $L=$ lumen, $P L=$ polymorphonuclear leucocyte, $E=$ endothelial cell, $B=$ basement membrane. Original magnification $\times 10000$ 


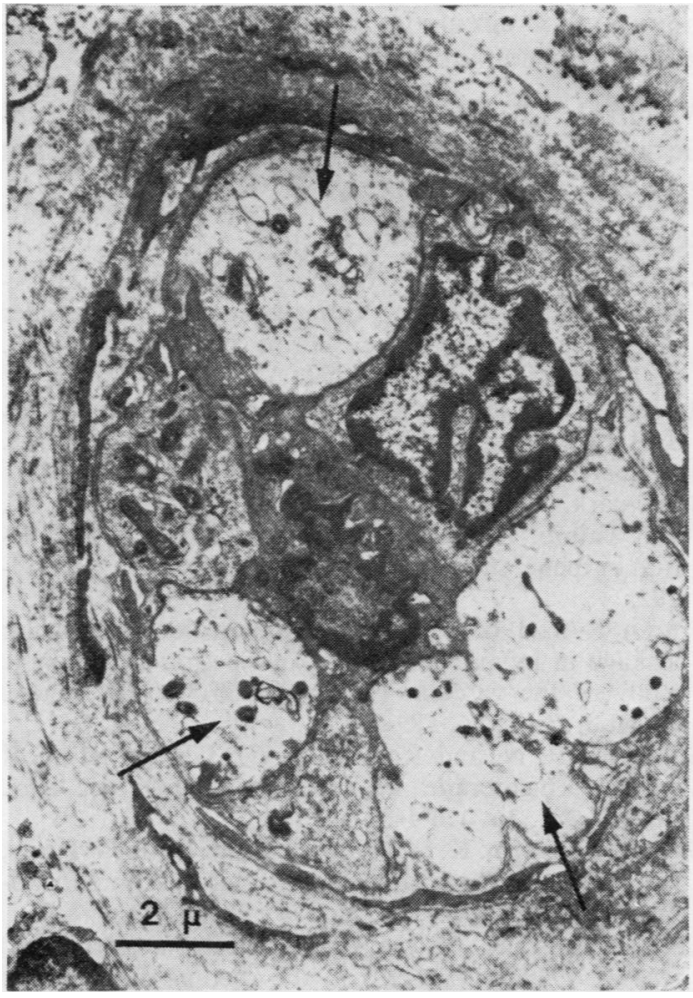

Fig. 9 Obliteration of capillary lumen by endothelial cells in normal synovial membrane. Significant cytoplasmic expansion by severe oedema (arrows). Original magnification $\times 4500$

inflammatory synovitis we did not find more capillaries with high endothelium and multilayered basement membrane, as described by Norton and Ziff (1966) in rheumatoid synovitis and by Schumacher and Kitridou (1972) in synovitis of recent onset. Norton et al. (1966) noted fenestrated capillaries more often in Reiter's synovial membrane than in rheumatoid arthritis. We found only a preferential site in the superficial layer of all synovial membranes, whether normal or inflammatory. As with light microscopy, we did not find any specific ultrastructural changes in the capillary wall in inflammatory synovitis. The number of intraendothelial microfibrils, increased in rheumatoid arthritis according to Ghadially and Roy (1967), appeared to us identical in all synovial membranes. In the case of systemic lupus erythematosus we did not find any destruction of the capillary endothelium, as reported by Schumacher and Kitridou (1972). However, in our patient numerous intraergastoplasmic tubular formations, originally described by Györkey et al. (1969) and first reported in synovial vascular endo-

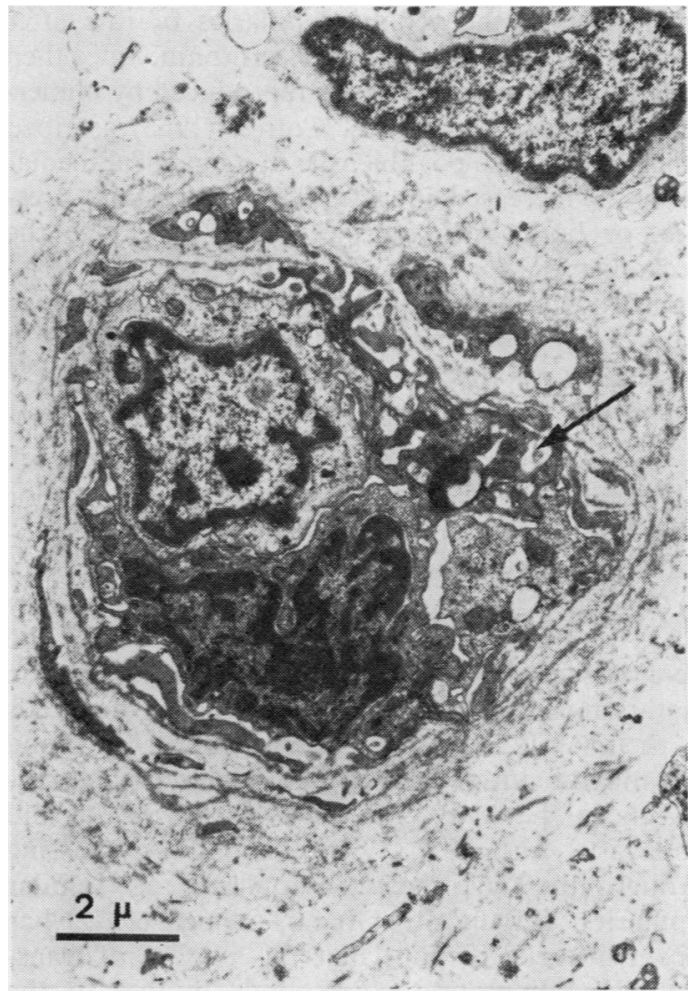

Fig. 10 Obliteration of capillary lumen by endothelial cells in normal synovial membrane. Important retraction of the cytoplasm (arrow). Original magnification $\times 4500$

thelium by Schumacher (1970), were found in the synovial capillary endothelium.

Extravascular plasma diffusion, interendothelial gaps A pattern suggesting extravascular plasma diffusion has not so far been mentioned. However, Brånemark et al. (1969) showed pictures of normal and rheumatoid synovial membranes which suggested to us the existence of extravascular plasma diffusion. Interendothelial gaps were not found by Norton and Ziff (1966) or by Brånemark et al. (1969) in normal and rheumatoid synovial membranes. However, in Reiter's synovitis an opening in the endothelium was mentioned by Norton et al. (1966). Schumacher (1969) found gaps in capillaries of monkey synovial membrane more often after prolonged joint motion than at rest. In synovitis of recent onset these interendothelial gaps were often found by Schumacher and Kitridou (1972). The significance of and the mechanism inducing the appearance of these interendothelial gaps have not yet been completely elucidated. Majno and Palade (1961) described their 
appearance in the venous capillaries of rats after local injection of histamine and serotonin. Since then these vascular gaps have been reproduced by numerous experimental methods. Cotran (1965) ascribed their origin to the possible role of a chemical mediator or to increased intracapillary hydrostatic pressure, or both. Although we cannot prejudge the mechanism responsible in our study the traumatism of the trochar biopsy may possibly be responsible for these interendothelial gaps by both releasing a chemical mediator and increasing intracapillary hydrostatic pressure.

Extracapillary blood cell migration The major difference between normal and inflammatory synovial capillaries consists in the number and diversity of the blood cells migrating out of the capillary lumen in rheumatoid and subacute synovitis. The pre-eminence of polymorphonuclear leucocyte migration is in accordance with the role of these cells in rheumatoid synovial inflammation. All blood cells migrate out of the capillary lumen by the interendothelial pathway. We did not observe, as did Kobayashi and Ziff (1973), lymphocytes passing through the endothelial cytoplasm of venular capillaries. On the other hand, Schoefl (1972) has shown in serial sections that this pattern of transendothelial migration corresponds in fact to the interendothelial passages.

Vascular congestion and obliteration of capillary lumen by endothelial cells Vascular congestion with packing of red blood cells in the synovial capillary lumen was not associated with ultrastructural changes in the capillary wall. We did not find the intracapillary aggregates of platelets, polymorphonuclear neutrophils, and red blood cells which Norton et al. (1966) described in Reiter's synovial membrane and Schumacher and Kitridou (1972) in synovitis of recent onset. Obliteration of the capillary lumen by endothelial cells was reported by Norton and Ziff (1966) in rheumatoid synovitis and by Schumacher and Kitridou (1972) in synovitis of recent onset. However, these authors did not describe ultrastructural changes in the endothelial cells. In our study this pattern, as common in controls as in inflammatory synovitis, might have been due to mechanical damage by the trochar to the loose tissue of the synovial membrane. We did not find, as did Bierther and Wegner (1971), a progressive transformation of the endothelial cells to fibroblasts in rheumatoid synovitis.

Our study shows, as reported by Brånemark et al. (1969), that synovial inflammation does not change the structure of the capillaries, but the transcapillary migration of circulating blood cells is greatly in? creased in rheumatoid and subacute synovitis.

We thank Miss Marie-France Corruble for tecto nical assistance. This work was supported by a grar产 from INSERM, Paris, Cat. No. 72.2.471.11.

\section{References}

Bierther, M. F. W. and Wegner, K. W. (1971). Elek" tronenmikroskopische Untersuchungen synoviale $\vec{D}$ Gefässveränderungen bei chronischer Polyarthritis... Z. Rheumaforsch., 30, 214-222.

Brånemark, P. I., Erkholm, R., and Goldie, I. (1969 To the question of angiopathy in rheumatoid arthritio Acta orthop. scand., 40, 153-175.

Brånemark, P. I., Lindström, J., Jonsson, I., Laine, V.ं and Vainio, K. (1963). Capillary structure and funcis tion in rheumatoid arthritis. Acta rheum. scand., 9, 28 \& 292.

Cotran, R. S. (1965). The delayed and prolonged vascular leakage in inflammation: II. An electron microscopic study of the vascular response after thermal injury Amer. J. Path., 46, 589-620.

Ghadially, F. N. and Roy, S. (1967). Ultrastructure $\overrightarrow{Q b}$ synovial membrane in rheumatoid arthritis. AnN rheum. Dis., 26, 426-443.

Györkey, R., Min, K. W., Sincovics, J. G., and Györkeyo P. (1969). Systemic lupus erythematosus and myxo virus (Letter). New Engl. J. Med., 280, 333.

Kobayashi, I. and Ziff, M. (1973). Electron microscop studies of lymphoid cells in the rheumatoid synovig membrane. Arthr. and Rheum., 16, 471-486.

Kulka, J. P. (1966). Vascular derangement in rheumatois arthritis. In Modern Trends in Rheumatology, edited bF A. G. S. Hill, pp. 49-69. Butterworths, London.

Majno, G. and Palade, G. E. (1961). Studies on inflamemation: I. The effect of histamine and serotonin of vascular permeability. An electron microscopic study J. biophys. biochem. Cytol., 11, 571-600.

Norton, W. L., Lewis, D., and Ziff, M. (1966). Light ang electron microscopic observations on the synovitis of Reiter's disease. Arthr. and Rheum., 9, 747-757.

Norton, W. L. and Ziff, M. (1966). Electron microscopte observations on the rheumatoid synovial membrane Arthr. and Rheum., 9, 589-610.

Ropes, M. W., Bennett, G. A., Cobb, S., Jacox, R., an Jessar, R. A. (1958). 1958 revision of diagnostic criteriø for rheumatoid arthritis. Bull. rheum. Dis., 9, 175-17\% Schoefl, G. I. (1972). The migration of lymphocytes across the vascular endothelium in lymphoid tissué A reexamination. J. exp. Med., 136, 568-588.

Schumacher, H. R. Jr. (1969). The microvasculature of the synovial membrane of the monkey: ultrastructurat studies. Arthr. and Rheum., 12, 387-404.

Schumacher, H. R. Jr. (1970). Tubular paramyxovirust like structures in synovial vascular endothelium. $A n n$ rheum. Dis., 29, 445-447.

Schumacher, H. R. and Kitridou, R. C. (1972). Synovit of recent onset: a clinico-pathologic study during the first month of disease. Arthr. and Rheum., 15, 465-485 Simon, G. (1965). Ultrastructure des capillaires. Angiog logica, 2, 370-434. 